\title{
Germline BRCA1 Gene Mutation
}

National Cancer Institute

\section{Source}

National Cancer Institute. Germline BRCA1 Gene Mutation. NCI Thesaurus. Code C150629.

A change in the nucleotide sequence of the BRCA1 gene that originates in the gametes. 